\title{
The Effect of Principal's Managerial Ability, Work Motivation, Job Satisfaction on the Performance of Kindergarten Teachers in Medan Perjuangan District
}

\author{
Diana $^{1}$ Biner Ambarita ${ }^{2}$ Mian Siahaan ${ }^{3}$ \\ \{aifenzhong@gmail.com ${ }^{1}$, miansi1960@gmail.com ${ }^{3}$ \} \\ ${ }^{1,2,3}$ Universitas Negeri Medan, Medan, Indonesia
}

\begin{abstract}
This study aims to determine the effect of Principal's Managerial Ability on Job Satisfaction, the effect of Work Motivation on Job Satisfaction, the effect of Principal's Managerial Ability on Teacher Performance, the effect of Work Motivation on Teacher Performance and the effect of Job Satisfaction on the Performance of Kindergarten Teachers in Medan Perjuangan District. This study uses path analysis with 112 teachers as research respondents. The sampling technique uses Random Sampling and data collection was obtained through a questionnaire. The findings of the study indicate the Principal's Managerial Ability has a direct positive effect on Job Satisfaction. Work motivation has a direct positive effect on job satisfaction. The Principal's Managerial Ability has a direct positive effect on Teacher Performance, Work Motivation has a direct positive effect on Teacher Performance, and Job Satisfaction has a direct positive effect on Teacher Performance.
\end{abstract}

Keywords: Principal's Managerial Ability, Work Motivation, Job Satisfaction, Teacher Performance.

\section{Introduction}

Education really determines the progress and quality of a nation. The quality of education affects the quality of the nation. Developed nations have good education. Good education is obtained from the quality of good teachers. The teacher is a key factor in the quality of education and progress of a nation. In line with the sentence above, teachers determine the success of a country's education because teachers are learning leaders, facilitators, and are also central to learning initiatives[1].The teacher as one of the educators, occupies a very important position, with his professionalism and close relations with students, he plays a role in creating a conducive learning environment. Law No. 20 of 2003 concerning the National Education System states that educators are professionals who are tasked with planning and implementing the learning process, assessing learning outcomes, conducting guidance and training, and conducting research and community service [2].

The task of a teacher is indeed hard, in addition to being an educator; the teacher must also be a manager who will manage everything related to the administration of learning in the classroom. Starting from the planning, organizing, controlling, and evaluating learning that has been done by the teacher in the learning process. If a teacher does not have high professionalism, the performance created will not run optimally [1]. Based on the explanation above, it can be concluded that improving or not the quality of education is influenced by the 
professional abilities of teachers and the quality of their performance, so that teachers are required to have good performance in order to achieve good quality education so that the quality of the nation increases. Based on preliminary observations in the city of Medan, researchers also found that there are still many teachers who have educational backgrounds graduating from other majors and not Early Education such as economics graduates, literary scholars, computer scholars and there are even teachers whose educational background are high school graduates. besides that there are still many teachers who have not yet followed basic education and training so that they do not understand the making of a Learning Implementation Plan (RPP) that is in accordance with the demands of K13 namely a scientific approach then creativity in making learning media is also lacking and the teaching methods are still monotonous and tend to be text books.
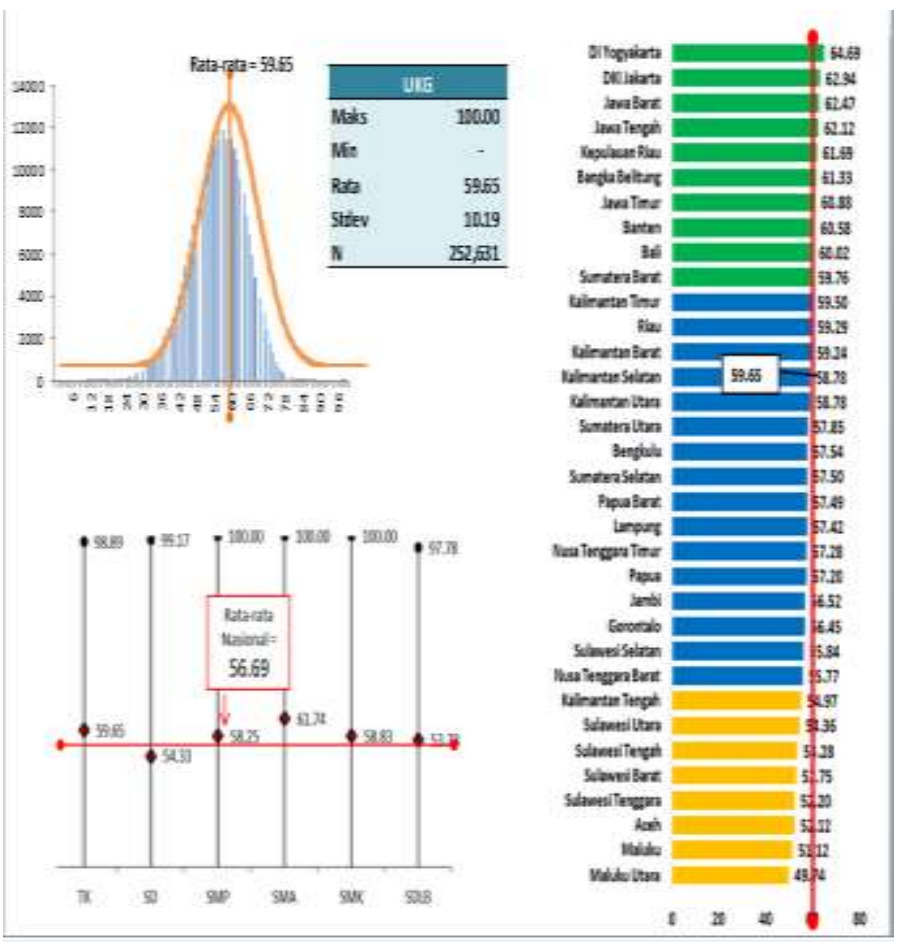

Fig 1. UKG Results of Teacher Pedagogic and Professional Competencies

Furthermore, from the 2015 UKG results of TK level, North Sumatra was ranked 16th, with an average of 57.85 while the national average was 59.65. There are 252631 teachers who attended this competency test. This shows that the UKG results, which were tested, were professional competence and pedagogical competence in northern Sumatra for kindergarten teachers was still low [3]. Teacher performance actually experienced a slight increase but it was still low because this happened because there were still many teachers who were difficult or difficult for him to keep up with the changing times. Not a few of the teachers who prefer to carry out the task as is usually done from time to time. This kind of situation shows the tendency of teacher behavior that is more directed to maintain the usual way of doing the task, 
or want to maintain the usual way of doing the task or want to keep the old way (conservative), given the way that is considered new generally requires various changes in work patterns [4]. Based on the description above, researchers are interested in conducting research with the title "The Effect of Principal's Managerial Ability, Work Motivation, Job Satisfaction on the Performance of Kindergarten Teachers in Medan Perjuangan District".

Ethically the term performance is a translation of the word performance which comes from the word to perform which means (1) achievement, (2) implementation, (3) achievement and (4) performance or appearance work [5]. Performance is (1) something that is achieved (2) achievement is shown (3) work ability [6]. Definition of performance in terms of definitive is the definition expressed by experts; there are those who formulate the notion of performance from the point of view of the results and productivity of a job. Performance is an activity carried out to carry out and complete certain tasks with full responsibility in accordance with the expectations and goals set previously [1]. Performance is an expression of the behavior of a person or organization with an achievement orientation [5]. Manifestation of behavior produced by someone in the organization in the form of results that come out of a job that is a contribution to the organization. The results of this work are also referred to as achievements produced by someone in the organization whereas performance is the work of someone in a certain period compared to several possibilities, such as target standards, targets, predetermined criteria [1]. Based on several explanations about the term performance, it can be concluded that the teacher's performance is all activities carried out in carrying out his mandate and responsibilities in educating, teaching, guiding, directing, guiding students in achieving maturity and maturity levels. Managerial in Indonesian Dictionary is related to managers. So in this case the manager must be able to master managerial science properly so that he can manage everything correctly. Management is said to be a process of planning, organizing, leading and supervising the work of organizational members and using all available organizational resources to achieve clearly stated organizational goals[7].

Management is the achievement of organizational goals in an effective and efficient way through planning, organizing, leading and overseeing organizational resources [8]. A similar understanding, which states that management is the process of planning, organizing, leading and overseeing the use of resources for performance purposes. Managerial ability is the ability to move others in utilizing existing resources in achieving organizational goals effectively and efficiently [9]. At school the principal acts as the education manager. The principal is an education manager who embodies the utilization of each school personnel appropriately in order to be able to carry out their duties optimally to obtain the best results, both in terms of numbers and in the teaching and learning process [10]. Based on the above opinion it can be concluded that the understanding of the principal's managerial ability is the ability to manage which contains a process of planning, organizing, leading and overseeing organizational resources so that they can run effectively and efficiently so that organizational goals can be achieved.

Motivation is a potential force that is in a human being, which can be developed alone or developed by a number of outside forces which in essence revolves around monetary rewards and non-monetary rewards, which can affect work results positively or negatively, which thing depends on the situation and conditions faced by the person concerned [11]. Motivation is a condition of inner effort that drives one's movements[12]. Desires or impulses arising from human beings will be or manifested through real behavior that can meet the desired needs. Motivation concerns how to direct the power and potential of someone (subordinates) to want to work together productively to achieve goals[13]. Motive is a driving force that moves people to behave in order to achieve goals, while motivation is something that gives 
rise to these motives [14]. Motivation (motivation) as a process that explains the intensity, direction, and perseverance of an individual to achieve his goals [15].

Based on the description above, work motivation is defined as something generate enthusiasm or drive to work, in work psychology work motivation is also called work motivation. job satisfaction as a general attitude of an individual and how much they believe they should receive [15]. Job satisfaction is determined by several factors namely mentally challenging work, supportive working conditions, supportive coworkers, and compatibility of personality with work. job satisfaction is a pleasant or unpleasant emotional state in which someone views their work [16]. Furthermore it is said that job satisfaction reflects a person's feelings towards his work, which can be seen from the positive attitude of workers towards their work and everything faced in the work environment. In addition job satisfaction can also be interpreted as an effectiveness or emotional response to various aspects of work [17]. Teacher job satisfaction is an emotional state experienced by teachers because of its relationship with their duties and obligations as educators in schools. Someone with a high level of job satisfaction shows a positive attitude towards the job, while someone who is dissatisfied with the job shows a negative attitude towards the job [18]. Based on several definitions of job satisfaction above, it can be interpreted that job satisfaction is a response that describes the feelings of individuals towards their work. Teacher job satisfaction is a reflection of the feelings experienced by teachers relating to their work as teaching staff.

\section{Research method}

This research used a quantitative approach, namely research used to examine populations and certain samples and used data collection with research instruments that aim to test the hypotheses that have been set. This research was carried out in Kinderganden Medan Perjuangan District, North Sumatera Province in September 2019 for one month. The population in this study were all 156 of teachers in Kinderganden Medan Perjuangan District with a total sample of 156 respondents.

\section{Result and discussion}

\section{The effect principal's managerial ability (x1) on job satisfaction (x3)}

Based on the results of the study, Principal's Managerial Ability (X1) has a positive direct effect on Job Satisfaction the of Kindergarden Teachers in Medan Perjuangan District. From the calculation results obtained by the path coefficient of the influence of the Principal's Managerial Ability (X1) on Job Satisfaction $(X 3)=\rho_{31}=0.336$ with a coefficient value of $t=$ 2,429 and with a significance of $p=0.000$ or a t-value greater than the value of $t_{\text {table }} \alpha(0.05)$ $=1,960$ so that Ho is rejected and Ha is accepted. Thus, it can be concluded that Principal's Managerial Ability has a direct positive effect on the teacher's Job Satisfaction of Kindergarden Teachers in Medan Perjuangan Distric. So that means, the higher the Principal's Managerial Ability of each teacher in the school, the better the Job Satisfaction. In other words, the pros and cons of Job Satisfaction of Kindergarden Teachers in Medan Perjuangan Distric are very much determined by the level of Principal's Managerial Ability of each teacher in the school.

\section{The effect of work motivation (x2) on job Satisfaction (x3)}


Based on the results of the study, the Work Motivation (X2) has a positive direct effect on teacher's Job Satisfaction (X3) of Kindergarden Teachers in Medan Perjuangan Distric. From the calculation results obtained by the path coefficient value of the influence of the Work Motivation on Job Satisfaction at $\rho_{32}=0.208$ with a coefficient value of $t_{\text {count }}=2,299$ and the significance of 0.000 or $\mathrm{t}_{\text {count }}$ value is greater than the value of the table $\alpha(0.05)=$ 1,960 so that Ho is rejected and Ha is accepted. Thus, it can be concluded that the Work Motivation has a direct positive effect on the teacher's Job Satisfaction of Kindergarden Teachers in Medan Perjuangan Distric. Then it means, the better the Teacher's Work Motivation, the higher the Job Satisfaction of the teacher. In other words, the level of teacher's Job Satisfaction of Kindergarden Teachers in Medan Perjuangan Distric is largely determined by the pros and cons of the teacher's Work Motivation.

\section{The effect of principal's managerial ability (x1) on teacher performance $(\mathrm{x} 4)$}

Based on the results of the study, Principal's Managerial Ability (X1) has a positive direct effect on Teacher Performance (X4) of Kindergarden Teachers in Medan Perjuangan Distric. From the calculation results obtained by path analysis the path coefficient value of the influence of Principal's Managerial Ability on Teacher Performance at $\rho_{41}=0.322$ with a coefficient value of tcount $=2,414$ and a significance of 0.000 or a value of tcount greater than the value of the table $\alpha(0.05)=1.960$ so Ho is rejected and Ha accepted. Thus, it can be concluded that Principal's Managerial Ability has a direct positive effect on Teacher Performance of Kindergarden Teachers in Medan Perjuangan Distric. So that means, the higher Principal's Managerial Ability of each teacher in the school, the higher Teacher Performance. In other words, the level of Teacher Performance in Medan Perjuangan Distric is very much determined by the level of Principal's Managerial Ability of each teacher in the school.

\section{The effect of work motivation (x2) on teacher performance (x4)}

Based on the results of the study, the Work Motivation (X2) has a positive direct effect on Teacher Performance (X4) of Kindergarden Teachers in Medan Perjuangan Distric. From the calculation results obtained by the path analysis shows that the path coefficient value of the influence of Work Motivation on Teacher Performance at $\rho_{42}=0.319$ with a coefficient value of $t=2,533$ and the significance of 0.003 or $t_{\text {count }}$ value is greater than the value of the table $\alpha(0.05)=1.960$ so Ho rejected and Ha accepted. Thus, it can be concluded that Work Motivation has a positive direct effect on the Teacher Performance of Kindergarden Teachers in Medan Perjuangan Distric. Therefore, that means, the better the Teacher's Work Motivation, the higher the Teacher Performance. In other words, the level of Teacher Performance in Medan Perjuangan Distric is highly determined by the pros and cons of the teacher's Work Motivation.

\section{The effect of job Satisfaction (x3) on teacher performance $(x 4)$}

Based on the results of the study, Job Satisfaction (X3) has a positive direct effect on Teacher Performance (X4) of Kindergarden Teachers in Medan Perjuangan Distric. From the calculation results obtained by path analysis the path coefficient value of the influence of Job 
Satisfaction on Teacher Performance at $\rho_{43}=0.372$ with a coefficient value of $t_{\text {count }}=4,970$ and the significance of 0.000 or $t_{\text {count }}$ value is greater than the value of the table $\alpha(0.05)=$ 1.960 so Ho is rejected and Ha accepted. Thus, it can be concluded that Job Satisfaction has a direct positive effect on the Teacher Performance of Kindergarden Teachers in Medan Perjuangan Distric. Therefore, that means, the better Job Satisfaction, the higher the Teacher Performance. In other words, the level of Teacher Performance of Kindergarden Teachers in Medan Perjuangan Distric is highly determined by the pros and cons of Job Satisfaction

\section{Conclusion}

Principal's Managerial Ability has a direct positive effect on the Job Satisfaction of Kindergarten Teachers in Medan Perjuangan District. The Work Motivation has a positive direct effect on the Job Satisfaction of Kindergarten Teachers in Medan Perjuangan District. Principal's Managerial Ability has a positive direct effect on the teacher's Performance of Kindergarten Teachers in Medan Perjuangan District. The Work Motivation has a positive direct effect on the teacher's Performance of Kindergarten Teachers in Medan Perjuangan District. Job Satisfaction has a direct positive effect on the teacher's Performance of Kindergarten Teachers in Medan Perjuangan District.

\section{References}

[1] Supardi, Teacher Performance. Jakarta: Raja Grafindo Persada, 2014

[2] Republic of Indonesia. 2003. Law on National Education System No. 20 of 2003. Concerning National Education Standards

[3] PPPTK

[4] Ali, Muhammad, $\mathrm{H}$ Concept and Application of CBSA in Teaching. Bandung: Bachelor of Karia, 1998.

[5] Barnawi and Arifin. M, Professional Teacher Performance: Guiding, Enhancing and Assessment Instruments. Yogjakarta: Ar-Ruzz Media, 2014

[6] Large Indonesian Dictionary, Ministry of National Education. Library Center, 2002.

[7] Stoner, A.F. James, Management Jakarta: Intermedia, 1922

[8] Daft, Richard I., Management Chicago: The Dryden Press, 1988

[9] Siahaan, Mian, SMK Principal Performance in terms of School Climate Factors, Managerial Competencies, Supervision Competencies and Entrepreneurship Competencies in North Sumatra Province, 2003.

[10] Nawawi, Educational Administration. Jakarta: Mount Agung.1989

[11] Winardi, Performance Management, Jakarta: Raja Grafindo Persada, 2007.

[12] Steers, Richard, M., Organizational Effectiveness: Code of Conduct, Management Series No. 147 translations. Jakarta: Magdalene, 1987.

[13] Hasibuan, Malayu, Human Resource Management. Jakarta: Earth Literacy, 2005.

[14] As'ad, Moh, Industrial psychology. Yogyakarta: Liberty, 1987.

[15] Robbins S.P. \& Judge, Timothy A., Organizational Behavior Issue 12. Translated by Angelica, Diana, Cahyani, Ria, Rosyid and Abdul. Jakarta: Salemba Empat, 2009

[16] Handoko, H., Personnel Management and Human Resources. Edition 2. Yogyakarta: BPFE Yogyakarta, 2008. 
[17] Kreitner, Organizational behavior. In E. Fifth. Book 1. Jakarta: Four Salemba 2005.

[18] Schermerhon, J.R., Management Translation: Parnawa Putranta. Yogyakarta: Andi Offset, 2010. 